\title{
Identification of protease and rpoN-associated genes of uropathogenic Proteus mirabilis by negative selection in a mouse model of ascending urinary tract infection
}

\author{
Hui Zhao, ${ }^{1}$ Xin Li, ${ }^{1}$ David E. Johnson ${ }^{2}$ and Harry L. T. Mobley ${ }^{1}$ \\ Author for correspondence: Harry L. T. Mobley. Tel: +1 410706 0466. Fax: +1 4107066751 . \\ e-mail: hmobley@umaryland.edu
}

Department of

Microbiology and

Immunology ${ }^{1}$ and

Department of Veterans

Affairs Medical Center2,

University of Maryland

School of Medicine,

$655 \mathrm{~W}$. Baltimore Street,

Baltimore, MD 21201, USA
Proteus mirabilis, a motile Gram-negative bacterium, is a principal cause of urinary tract infections in patients with functional or anatomical abnormalities of the urinary tract or those with urinary catheters in place. Thus far, virulence factors including urease, flagella, haemolysin, various fimbriae, IgA protease and a deaminase have been characterized based on the phenotypic traits conferred by these proteins. In this study, an attempt was made to identify new virulence genes of $P$. mirabilis that may not have identifiable phenotypes using the recently described technique of signature-tagged mutagenesis. A pool of chromosomal transposon mutants was made through conjugation and kanamycin/tetracycline selection; random insertion was confirmed by Southern blotting of chromosomal DNA isolated from 16 mutants using the aphA gene as a probe. From the total pool, $2 \cdot 3 \%$ (9/397) auxotrophic mutants and $3.5 \%(14 / 397)$ swarming mutants were identified by screening on minimal salts agar and Luria agar plates, respectively. Thirty per cent of the mutants, found to have either no tag or an unamplifiable tag, were removed from the input pool. Then $10^{7}$ c.f.u. from a 96-mutant pool ( $\sim 10^{5}$ c.f.u. of each mutant) were used as an input pool to transurethrally inoculate seven CBA mice. After $2 \mathrm{~d}$ infection, bacteria were recovered from the bladders and kidneys and yielded about $10^{5}$ c.f.u. as an output pool. Dot blot analysis showed that two of the 96 mutants, designated B2 and B5, could not be hybridized by signature tags amplified from the bladder output pool. Interrupted genes from these two mutants were cloned and sequenced. The interrupted gene in B2 predicts a polypeptide of $37.3 \mathrm{kDa}$ that shares amino acid similarity with a putative protease or collagenase precursor. The gene in B5 predicts a polypeptide of $32.6 \mathrm{kDa}$ that is very similar to that encoded by ORF284 of the rpoN operon controlling expression of nitrogen-regulated genes from several bacterial species. The virulence of the two mutants was tested further by co-challenging CBA mice with each mutant and the parental strain. After 1 week of infection, the B2 and B5 mutants were recovered in numbers 100-fold and 1000-fold less than the parental strain, respectively. Using an in vitro assay, it was shown that the B2 mutant had significantly less $(P=0.0001)$ extracellular protease activity than the wild-type strain. These findings demonstrate that signaturetagged mutagenesis is a viable approach to identify bacterial genes associated with the ability to infect the urinary tract.

Keywords: urinary tract infection, signature-tagged mutagenesis (STM), Proteus mirabilis, CBA mouse 


\section{INTRODUCTION}

Proteus mirabilis, a common uropathogen, is frequently isolated from the urine of hospitalized patients and individuals with indwelling urinary catheters. Infection with this organism can result in serious complications including acute pyelonephritis, stone formation in the bladder and kidney, encrustation and obstruction of the catheter, fever and bacteraemia (Griffith et al., 1976; Mobley \& Warren, 1987; Rubin et al., 1986). After Escherichia coli, P. mirabilis is the second leading cause of bacteraemia in the elderly (Setia et al., 1984).

Thus far, several virulence determinants including urease (Griffith et al., 1976; Mobley \& Warren, 1987; Jones et al., 1990; Johnson et al., 1993b), fimbriae (for review see Mobley \& Belas, 1995), flagella (Belas \& Flaherty, 1994; Allison et al., 1994; Mobley et al., 1996), haemolysin (Swihart \& Welch, 1990; Mobley et al., 1991), IgA protease (Senior et al., 1987, 1991; Loomes et al., 1990; Wassif et al., 1995) and amino acid deaminase (Massad et al., 1995) have been described for this species. The genes encoding these proteins have been isolated and sequenced and some of the corresponding proteins have been purified and characterized. To determine the contribution to pathogenesis of each virulence determinant, isogenic mutants have been constructed for most of these genes and tested for virulence in a CBA mouse model of ascending urinary tract infection (UTI). By these systematic studies, urease, flagella and mannose-resistant/Proteus-like (MR/P) fimbria have been found to contribute most significantly to the pathogenesis of acute pyelonephritis. P. mirabilis fimbriae (PMF) and haemolysin also contribute to virulence but appear to play more subtle roles (Massad et al., 1994; Mobley, 1996).

Thus far, we have identified genes, suggested to play a role in virulence, that have a clear and measurable phenotype. To identify and assess the function of additional virulence factors for which phenotypes may not easily be recognized by plate assays, signaturetagged mutagenesis, a newly described genetic approach (Hensel et al., 1995), was used in this study. In this technique, transposon mutagenesis is used to make chromosomal mutations. However, the transposon has been modified by adding unique 80 bp tags which can be identified by PCR and colony blot or dot blot hybridization. A mixed population of mutants, as an input pool, are inoculated into an appropriate animal model. After a defined period of infection, animals are killed and mutants with attenuated virulence (those not recovered) can be identified by hybridizing the tags from the recovered pool and comparing those present in the input pool. The genes interrupted by a transposon are cloned and sequenced. The function of the genes may be predicted by a sequence similarity search with a database. This system was developed and has been used successfully in Salmonella typhimurium and Staphylococcus aureus by D. W. Holden and colleagues (Hensel et al., 1995; Shea et al., 1996; Mei et al., 1997) and others (Schwan et al., 1998) and in Vibrio cholerae (Chiang \&
Mekalanos, 1998), typically in models where high concentrations of organisms are recovered from tissue.

Reliable selection of mutants using signature-tagged mutagenesis is heavily dependent on the animal model. Since ascending infection is thought to be the most frequent route of human UTI, a well-established mouse model of ascending UTI (Hagberg et al., 1983; Johnson et al., 1987) was used in our study. This mouse model has been successfully used by our group to assess the uropathogenicity of E. coli (Johnson et al., 1993a), Providencia stuartii (Johnson et al., 1987) and $P$. mirabilis (Johnson et al., 1993b). In this report, we describe the use of signature-tagged mutagenesis for the isolation of newly identified virulence genes of uropathogenic $P$. mirabilis in the CBA mouse model of ascending UTI. While numbers of bacteria recovered from the bladders of infected mice in these studies did not reach levels observed for other bacterial species in other animal models (Hensel et al., 1995; Shea et al., 1996; Mei et al., 1997; Schwan et al., 1998), the technique nevertheless appears useful for identification of virulence genes.

\section{METHODS}

Bacterial strains, plasmids and growth media. $P$. mirabilis HI4320 (urease-positive; produces MR/P, PMF and ambient temperature fimbriae; haemolysin-positive; $\mathrm{Tet}^{\mathrm{R}}$ ) was isolated from an elderly woman with urinary-catheter-associated bacteriuria (Mobley \& Warren, 1987; Warren et al., 1982). E. coli strain DH5 $\lambda$ pir was used to maintain the tagged $\mathrm{pUT} / \mathrm{mini}-\mathrm{Tn} 5$ plasmid pool and E. coli S17 $\lambda$ pir was used as a donor strain for conjugation with $P$. mirabilis HI4320 (recipient strain). E. coli DH5 $\alpha$ [supE44 $\Delta l a c U 169(\phi 80$ lacZ $\Delta M 15)$ hsdR17 recA1 endA1 gyrA96 thi-1 relA1] was used in cloning DNA. Luria broth $\left(1^{-1}: 10 \mathrm{~g}\right.$ tryptone, 5 g yeast extract and $5 \mathrm{~g} \mathrm{NaCl}$ ) and Luria agar (Luria broth containing $1.5 \%$ agar) were used as culture media. Nonswarming agar $\left(1^{-1}: 10 \mathrm{~g}\right.$ tryptone, $5 \mathrm{~g}$ yeast extract, $5 \mathrm{ml}$ glycerol, $0.4 \mathrm{~g} \mathrm{NaCl}$ and $29 \mathrm{~g}$ agar) was used to prevent swarming of $P$. mirabilis (Belas et al., 1991a). Minimal salts medium for Proteus sp. contained $\left(1^{-1}\right) 10.5 \mathrm{~g} \mathrm{~K}_{2} \mathrm{HPO}_{4}, 4.5 \mathrm{~g}$ $\mathrm{KH}_{2} \mathrm{PO}_{4}, 0.47 \mathrm{~g}$ sodium citrate and $1.0 \mathrm{~g}\left(\mathrm{NH}_{4}\right)_{2} \mathrm{SO}_{4}$; after autoclave sterilization, $1 \mathrm{ml} 1 \mathrm{M} \mathrm{MgSO}_{4}, 10 \mathrm{ml} \mathrm{20 \%} \mathrm{(v/v)}$ glycerol and $1 \mathrm{ml} 1 \%(\mathrm{w} / \mathrm{v})$ nicotinic acid were added to $1 \mathrm{l}$ medium prior to pouring. Nitrogen-limited medium $(\mathrm{Hu}$ et al., 1990) consisted of ammonium-free M9 medium (containing, $\mathrm{I}^{-1}, 6 \mathrm{~g} \mathrm{Na}_{2} \mathrm{HPO}_{4}, 3 \mathrm{~g} \mathrm{KH}_{2} \mathrm{PO}_{4}, 0.5 \mathrm{~g} \mathrm{NaCl}, 1 \mathrm{mM}$ $\mathrm{MgSO}_{4}, 0.4 \%$ glucose, $\mathrm{pH} 7.4$ ) and $10 \mathrm{mM}$ freshly prepared filter-sterilized L-glutamine or L-arginine. Nitrogen-excessive medium contained ammonium-free $\mathrm{M} 9$ medium and $\mathrm{NH}_{4} \mathrm{Cl}$ $(40,400$ and $800 \mathrm{mM})$.

Signature-tagged mutagenesis. Plasmid DNA representing the tagged pool (pUT/mini-Tn5 marked with random signature tags; $\mathrm{Amp}^{\mathrm{R}}$ ) (Hensel et al., 1995) was transformed into donor strain E. coli S17 גpir by electroporation. Transformants were pooled and stored in Luria broth with $15 \%$ $(\mathrm{w} / \mathrm{v})$ glycerol at $-70^{\circ} \mathrm{C}$. Recipient cells of $P$. mirabilis HI4320 $\left(\right.$ Tet $^{\mathrm{R}}$ ) were grown overnight at $37^{\circ} \mathrm{C}$ in Luria broth containing tetracycline $\left(20 \mu \mathrm{g} \mathrm{ml}^{-1}\right)$. Overnight culture $(50 \mu \mathrm{l})$ was inoculated into $5 \mathrm{ml}$ fresh Luria broth and grown to $\mathrm{OD}_{600} 0.5-1.0$; a large loopful of frozen donor cells of S17 ipir harbouring the tagged $\mathrm{pUT} / \mathrm{mini}-\mathrm{Tn} 5$ plasmid was inoculated 
into $3.5 \mathrm{ml}$ Luria broth and grown for $1.5 \mathrm{~h}$ to allow recovery of bacteria. In a 96-well microtitre plate, $50 \mu \mathrm{l}$ of each donor and recipient cells was mixed and a 48-well metal replicator was used to transfer samples of the strain suspensions from the microtitre dishes onto the non-swarming Luria agar plate. After overnight mating and growth, each mating suspension was restreaked onto non-swarming Luria agar plates containing kanamycin $\left(50 \mu \mathrm{g} \mathrm{ml}^{-1}\right)$ and tetracycline $\left(20 \mu \mathrm{g} \mathrm{ml}^{-1}\right)$. A single colony from each mating was selected at random and stored in a single microtitre plate well.

Southern blot analysis. Chromosomal DNA isolated from $P$. mirabilis transposon mutants was digested with restriction enzymes and electrophoresed on a $0.8 \%(\mathrm{w} / \mathrm{v})$ agarose gel, and transferred to a membrane (QIABRANE Nylon Plus; Qiagen). Probe labelling, hybridization and signal detection were carried out with the ECL direct nucleic acid labelling and detection system (Amersham Life Science) according to the instructions of the manufacturer.

Colony blot and dot blot hybridization. For colony blots, bacteria were grown directly on sterile nylon membranes overlaid onto dry non-swarming LB agar plates containing kanamycin $\left(50 \mu \mathrm{g} \mathrm{ml}^{-1}\right)$. Plates were incubated right side up overnight at $37^{\circ} \mathrm{C}$. Filters were prepared for hybridization as instructed by the manufacturer (Qiagen). DNA probes were labelled with $\left[{ }^{32} \mathrm{P}\right] \mathrm{dCTP}\left[3000 \mathrm{Ci} \mathrm{mmol}^{-1}\left(111 \mathrm{TBq} \mathrm{mmol}^{-1}\right)\right.$; Amersham] by hot PCR and hybridized to membranes under stringent conditions $\left(50 \%\right.$ formamide, washing at $\left.65^{\circ} \mathrm{C}\right)$. For dot blots, bacteria were lysed and DNA was denatured in $0.6 \mathrm{M} \mathrm{NaCl}, 0.2 \mathrm{M} \mathrm{NaOH}$ and $0.08 \%$ SDS for $10 \mathrm{~min}$ or more prior to blotting onto the membrane. Membranes were washed in $2 \times$ SSC $\left(1 \times\right.$ SSC contains, $1^{-1}, 8.765 \mathrm{~g} \mathrm{NaCl}, 4.41 \mathrm{~g}$ sodium citrate, $\mathrm{pH} 7.0$ ) and hybridized with probes under stringent conditions $\left(50 \%\right.$ formamide, washing at $\left.65^{\circ} \mathrm{C}\right)$.

Measurement of dot blot signals. The integrated density of each colony's dot blot signal from the autoradiographs was measured using the Eagle Eye II Still Video System (The Eagle Sight Software, version 3.0; Stratagene).

PCR. Transposon mutants (ranged in number from $10^{2}$ to $10^{5}$ ), grown on non-swarming agar plates, were collected using disposable inoculating loops and suspended in $50 \mathrm{mM}$ Tris, $\mathrm{pH} 8.5,1 \mathrm{mM}$ EDTA, $0.5 \%$ Tween 20 containing proteinase $\mathrm{K}\left(200 \mu \mathrm{g} \mathrm{ml} l^{-1}\right)$. Samples were incubated for $1 \mathrm{~h}$ at $55^{\circ} \mathrm{C}$ followed by incubation at $95^{\circ} \mathrm{C}$ for $10 \mathrm{~min}$ to inactivate the protease. A sample of the supernatant, typically $1-10 \mu \mathrm{l}$ in $100 \mu$ l PCR mixture, was used for amplification (Wright $\&$ Manos, 1990). For PCR, Taq DNA polymerase was used according to the directions of the manufacturer. After an initial denaturation of $4 \mathrm{~min}$ at $95^{\circ} \mathrm{C}$, the thermocycler was programmed for 20 cycles of $50^{\circ} \mathrm{C}$ for $45 \mathrm{~s}, 72^{\circ} \mathrm{C}$ for $10 \mathrm{~s}$ and $95^{\circ} \mathrm{C}$ for $30 \mathrm{~s}$. Primers P2 $\left(5^{\prime}\right.$ TACCTACAACCTCAAGCT $\left.3^{\prime}\right)$ and P4 (5' TACCCATTCTAACCAAGC $\left.3^{\prime}\right)$ were synthesized on an Applied Biosystems Automated DNA Synthesizer. The first PCR was performed in $100 \mu \mathrm{l}$ volumes. After ethanol precipitation, PCR products were purified by electrophoresis through a $1.6 \%(\mathrm{w} / \mathrm{v}\rangle$ Seaplaque agarose (FMC Bioproducts) gel in TAE buffer. Gel slices containing fragments of about $80 \mathrm{bp}$ were excised and a $2 \mu \mathrm{l}$ sample was used for the second PCR. This reaction was carried out in a total volume of $20 \mu \mathrm{l}$ and contained $50 \mu \mathrm{M}$ each of dATP, dTTP and dGTP and $\left.10 \mu \mathrm{l}{ }^{32} \mathrm{P}\right] \mathrm{dCTP}\left[3000 \mathrm{Ci} \mathrm{mmol}{ }^{-1}\right.$ (111 TBq $\mathrm{mmol}^{-1}$ ); Amersham]. The second PCR products were digested with HindIII to remove primer arms and used directly for hybridization (Hensel et al., 1995).

Molecular cloning and nucleotide sequencing. Chromosomal DNA was isolated from transposon mutants and digested with several restriction enzymes, including EcoRI, SmaI, PvuII, $N s i \mathrm{I}, D r a \mathrm{I}$ and $S s p \mathrm{I}$. Digests were electrophoresed through agarose gels and subjected to Southern blot analysis (as described above) using the kanamycin-resistance gene of $\mathrm{pUT} / \mathrm{mini}-\mathrm{Tn} 5-\mathrm{Kan}(1.7 \mathrm{~kb}$ EcoRI-XbaI fragment) as a probe. Restriction enzymes which gave rise to hybridizing fragments in the range $2 \cdot 5-10 \mathrm{~kb}$ were selected for digestion of DNA for cloning. Digested fragments were ligated into EcoRV-digested $\mathrm{pBluescript} \mathrm{KS}(-)$ and transformed into $E$. coli DH $5 \alpha$. Transformants were selected on LB plates containing kanamycin $\left(50 \mu \mathrm{g} \mathrm{ml}^{-1}\right)$. Sequencing was performed by the dideoxy chain-termination method with double-stranded DNA as the template. Reagents from the PRISM Ready Reaction DyeDeoxy Termination kit (Applied Biosystems) were used in conjunction with Taq polymerase (Boehringer Mannheim). Reactions were run on a model 373 DNA sequencer (Applied Biosystems).

CBA mouse model of ascending UTI. A modification (Johnson et al., 1987) of the mouse model of ascending UTI originally developed by Hagberg et al. (1983) was used. Female mice (20-22 g, 6-8 weeks old; Jackson Laboratory, Bar Harbour, ME, USA), tested for the absence of bacteriuria, were anaesthetized with methoxyflurane and inoculated with $P$. mirabilis HI4320 [approx. $10^{7}$ c.f.u. suspended in $0.05 \mathrm{ml} \mathrm{PBS}$ $\left(l^{-1}: 8 \mathrm{~g} \mathrm{NaCl}, 0 \cdot 2 \mathrm{~g} \mathrm{KCl}, 11.5 \mathrm{~g} \mathrm{Na}_{2} \mathrm{HPO}_{4} .7 \mathrm{H}_{2} \mathrm{O}, 2 \mathrm{~g}\right.$ $\left.\mathrm{KH}_{2} \mathrm{PO}_{4}\right): 10^{5}$ c.f.u. each of the 96 mutants] through a sterile polyethylene catheter inserted into the bladder through the urethra. After 1 week, the mice were killed by administration of an overdose of methoxyflurane. Urine was collected and the bladder and both kidneys were removed. Each sample was quantitatively cultured, and viable counts were determined as c.f.u. (ml urine) $)^{-1}$ or c.f.u. (g tissue) ${ }^{-1}$.

Proteolytic assay. A single colony of P. mirabilis HI4320 or its signature-tagged mutant was inoculated into Luria broth $(5 \mathrm{ml})$ and cultured overnight with shaking at $37^{\circ} \mathrm{C}$. The bacterial culture was diluted 1:50 into $100 \mathrm{ml}$ fresh Luria broth and incubated at $37^{\circ} \mathrm{C}$ with shaking until the $\mathrm{OD}_{600}$ reached approximately $1 \cdot 0$. For the supernatant fraction, $1 \mathrm{ml}$ cell culture was added to microcentrifuge tubes and subjected to centrifugation $\left(10000 \mathrm{~g}, 5 \mathrm{~min}, 4^{\circ} \mathrm{C}\right)$. Supernatants were collected and held on ice for assay on the same day. For periplasmic fractions, bacterial pellets from $3 \mathrm{ml}$ cultures were treated with $2 \mathrm{mg}$ polymyxin $\mathrm{B} \mathrm{m} \mathrm{l}^{-1}$ at $37^{\circ} \mathrm{C}$ for $30 \mathrm{~min}$ and the supernatants were separated from the pellet by centrifugation $\left(10000 \mathrm{~g}, 5 \mathrm{~min}, 4^{\circ} \mathrm{C}\right)$, collected and held on ice. The remaining overnight cultures were centrifuged $(7000 \mathrm{~g}$, $10 \mathrm{~min}, 4^{\circ} \mathrm{C}$ ) and the cell pellets were resuspended in $1.5 \mathrm{ml}$ Luria broth and lysed in a French pressure cell at 20000 p.s.i. $(138 \mathrm{MPa})$. After centrifugation $\left(27000 \mathrm{~g}, 20 \mathrm{~min}, 4^{\circ} \mathrm{C}\right)$, supernatants were collected and held on ice.

Triplicate samples from supernatant, periplasmic and cytoplasmic fractions $(300 \mu \mathrm{l})$ were added separately to microcentrifuge tubes containing $500 \mu \mathrm{l} 2 \%$ azocasein and $0.2 \%$ sodium azide in $50 \mathrm{mM}$ HEPES buffer $(\mathrm{pH} 7 \cdot 5)$. Tubes were incubated overnight at $37^{\circ} \mathrm{C}$. Trichloroacetic acid $(30 \%$ as final concentration) was added to precipitate undigested azocasein. After microcentrifugation, the $A_{400}$ of the supernatant from each tube was measured. Data are expressed as $A_{400}$ (ml original culture volume $)^{-1}$. Means of triplicate experiments were compared using the $t$-test.

Other assays. The $\gamma$-glutamyl transferase assay (Bender $e t a l$., 1977 ) is used to measure the total amount of glutamine synthetase activity (adenylated plus non-adenylylated enzyme). Urease activity was measured quantitatively by the phenol red spectrophotometric method of Hamilton-Miller \& 
Gargan (1977) as described previously (Jones \& Mobley, 1987). MR/P haemagglutination was demonstrated by the agglutination of untreated chicken erythrocytes (Bahrani \& Mobley, 1994; Bahrani et al., 1994).

\section{RESULTS}

\section{Preparation of the mutant pool}

A pool of mini-Tn5 transposon with signature tags was introduced into $P$. mirabilis chromosomal DNA by conjugation between E. coli S17 $\lambda$ pir (tagged pUT/miniTn5-Kan) as donor and $\operatorname{Tet}^{\mathrm{R}} P$. mirabilis HI4320 as recipient. Exconjugants were selected on non-swarming Luria agar plates containing kanamycin $\left(50 \mu \mathrm{g} \mathrm{m}{ }^{-1}\right)$ and tetracycline $\left(20 \mu \mathrm{g} \mathrm{ml}^{-1}\right)$. All $\mathrm{Kan}^{\mathrm{R}} \mathrm{Tet}^{\mathrm{R}}$ colonies were further screened for ampicillin susceptibility since some suicide plasmid pUT/mini-Tn5 might still be retained as a replicating plasmid in $P$. mirabilis. By screening on Luria agar plates containing ampicillin $\left(100 \mu \mathrm{g} \mathrm{ml}^{-1}\right)$ and tetracycline $\left(20 \mu \mathrm{g} \mathrm{ml}^{-1}\right)$, only a very few colonies were found to be $A m p^{R}$; these $A m p^{R}$ colonies were excluded from the mutant bank. Of 397 mutants examined, another $30 \%$ of colonies, with either no tag or an unamplifiable tag, were identified by colony blot hybridization and also removed from the mutant

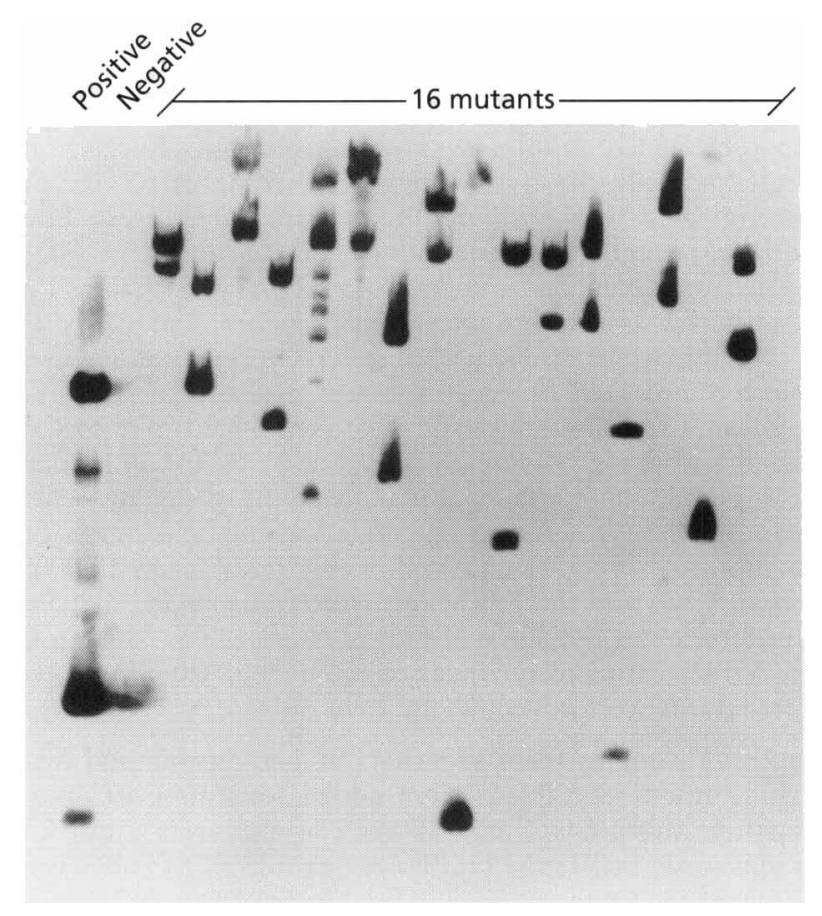

Fig. 1. Southern blot of randomly selected transposon mutants. Chromosomal DNA was prepared from 16 mutants randomly chosen from the pool of 96 mutants, using plasmid DNA with a tagged transposon as a positive control and the chromosomal DNA from the wild-type $P$. mirabilis as a negative control. All DNA samples were digested with $X h o l$, which has a unique restriction site inside the transposon. A $1.7 \mathrm{~kb}$ EcoRl-Xbal fragment carrying the kanamycin-resistance gene from the tagged plasmid was used as a probe by the ECL direct labelling system. pool. Thus approximately 280 colonies met criteria for inclusion.

To confirm that the transposon inserted into different sites within the chromosome of individual mutants, Southern hybridization was done using the $1.7 \mathrm{~kb}$ EcoRI-Xbal fragment (Lorenzo et al., 1990) carrying the kanamycin-resistance gene from plasmid pUT/miniTn5-Kan as a probe. Chromosomal DNA was isolated from 16 randomly picked mutants and digested with $X$ XoI, which has a unique restriction site inside the transposon (Fig. 1). None of the 16 mutants had comparable digestion patterns, suggesting that the insertions were random for the pool of transposon mutants.

As another index of random insertion, we screened for mutants that were incapable of swarming and for auxotrophic mutants by plating the mutants both on freshly prepared Luria agar and on minimal salts agar, respectively. We found approximately $3.5 \%$ swarming mutants (i.e. did not swarm) and $2.3 \%$ auxotrophic mutants (i.e. no growth on minimal medium). According to previous reports, at least 45 genes from the $P$. mirabilis genome are involved in directing motility, cell differentiation and multicellular behaviour, an important process for bacteria to colonize and ascend the urinary tract (Allison \& Hughes, 1991; Belas et al., 1991b); about 70 genes, when mutated, lead to auxotrophy (Belas et al., 1991a). The frequency of these mutations further suggested that the mutations were random and evenly distributed around the $P$. mirabilis chromosome (based on a genome size of $4.2 \mathrm{Mb}$; Allison \& Hughes, 1991).

\section{Experimental animal infection and dot blot analysis}

We used the CBA mouse model of ascending UTI, which mimics the natural route of the human infection (i.e. ascension of bacteria from the urethra to the bladder to the ureter to the kidney). Using 96 mutants as an input pool, we conducted animal infection studies for different periods of time and recovered the output pools from six mice after $2 \mathrm{~d}$ infection and six mice after $7 \mathrm{~d}$ infection. We found that infection for $2 \mathrm{~d}$ gave more reproducible results for bladder samples than $7 \mathrm{~d}$ infection; results from kidney samples have not been as reproducible (about $25 \%$ of the mutants are not recovered).

Two days after challenge, mice were killed and bacteria were recovered by plating bladder or kidney homogenates onto non-swarming Luria agar plates supplemented with kanamycin and tetracycline. The geometric means of $\log _{10}$ c.f.u. (ml urine) $)^{-1}$ or $\log _{10}$ c.f.u. (g bladder or kidney $)^{-1}$ were 8.86 for urine, 5.87 for bladder and 4.07 for kidney. These results are typical of experimental infection using this method (Bahrani \& Mobley, 1994; Jones et al., 1990; Mobley et al., 1996). Approximately $10^{5}$ c.f.u., recovered from each bladder, were used as an output pool.

An example of a dot blot analysis of an input pool and an output pool from the bladder of one experimentally 
(a) Input pool

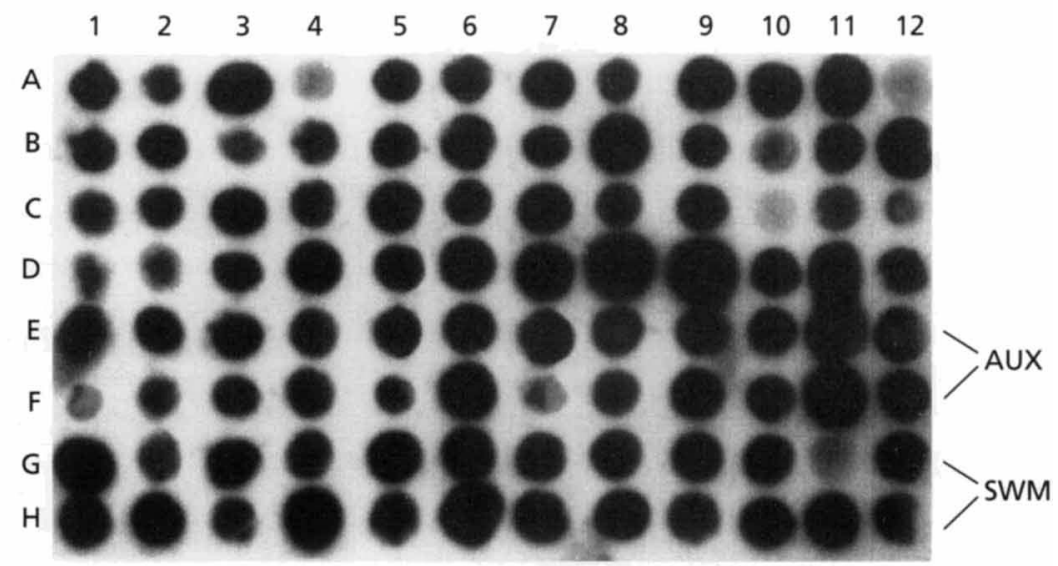

(b) Output pool

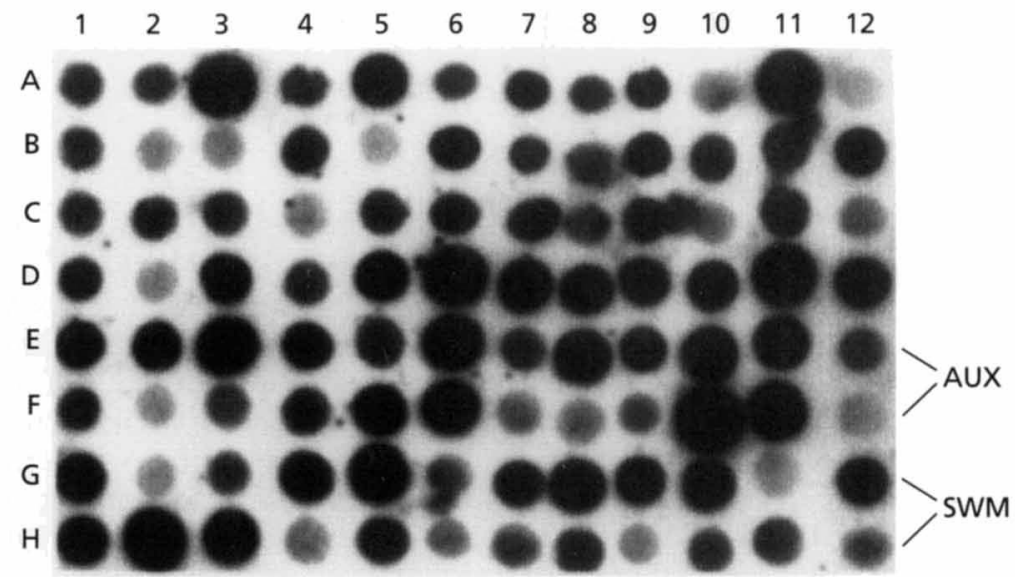

Fig. 2. Dot blot hybridization analysis from (a) the input pool and (b) the output poo from a bladder of an infected mouse. A pool of 96 mutants, including two auxotrophic mutants (E12 and F12) and two swarming mutants (G12 and H12), was inoculated into CBA mice. Two days after inoculation, bacteria were recovered from the bladders and represented the output pool. DNA isolated from approximately $10^{4}$ c.f.u. of the input pool or output pool was used as template for PCR amplification. ${ }^{32}$ P-labelled PCR products ( $80 \mathrm{bp}$ fragments containing pooled signature tags), digested with HindIII, were used as probes for hybridization of the dot blot membranes prepared from the 96 mutants.

Table 1. Densitometric analysis of autoradiographs of dot blots from the output and input pools of $P$. mirabilis signature-tagged transposon mutants inoculated into and recovered from the bladders of transurethrally challenged CBA mice

Each number represents the quantitative densitometric signal for the dot blot hybridization of the output pool (organisms recovered from the bladders of five mice following $2 \mathrm{~d}$ infection) divided by the densitometric signal for the dot blot hybridization of the input pool (organisms used to transurethrally challenge the mice). Mutants with ratios of $<0.15$ (underlined; B2 and B5) were selected for analysis. For each of the five mice the $\log _{10}$ c.f.u. (g bladder) ${ }^{-1}$ recovered $48 \mathrm{~h}$ after inoculation was $6 \cdot 691,6 \cdot 589,7 \cdot 078,4 \cdot 566$ and $7 \cdot 223$.

\begin{tabular}{|c|c|c|c|c|c|c|c|c|c|c|c|c|}
\hline & 1 & 2 & 3 & 4 & 5 & 6 & 7 & 8 & 9 & 10 & 11 & 12 \\
\hline A & $1 \cdot 26$ & $1 \cdot 10$ & $1 \cdot 10$ & $2 \cdot 50$ & 0.77 & 0.50 & 0.38 & 0.80 & 0.59 & $0 \cdot 24$ & $1 \cdot 25$ & 0.69 \\
\hline B & 0.75 & $\underline{0.13}$ & 0.74 & $0 \cdot 61$ & $\underline{0.04}$ & 0.69 & 0.72 & $0 \cdot 86$ & $0 \cdot 73$ & 0.94 & 0.87 & 0.75 \\
\hline $\mathrm{C}$ & 0.60 & 0.76 & 1.24 & 0.41 & 0.25 & $0 \cdot 30$ & 0.33 & $0 \cdot 27$ & $1 \cdot 11$ & $>10$ & 0.97 & $1 \cdot 48$ \\
\hline D & $1 \cdot 18$ & 0.42 & 1.67 & 0.34 & 0.94 & 1.09 & 0.92 & $0 \cdot 83$ & $0 \cdot 46$ & 0.54 & 0.91 & $1 \cdot 15$ \\
\hline $\mathrm{E}$ & 0.78 & 1.00 & $1 \cdot 18$ & 0.77 & 0.73 & $0 \cdot 80$ & 0.85 & 0.74 & 0.77 & $1 \cdot 16$ & 0.65 & 0.44 \\
\hline $\mathrm{F}$ & $>10$ & $1 \cdot 32$ & 0.90 & 0.68 & $1 \cdot 88$ & 0.94 & $5 \cdot 50$ & $0 \cdot 28$ & 0.52 & $1 \cdot 21$ & 1.06 & 0.54 \\
\hline $\mathrm{G}$ & 0.77 & 0.78 & $0 \cdot 81$ & 0.75 & 1.03 & 0.97 & 0.79 & $0 \cdot 78$ & $0 \cdot 91$ & $1 \cdot 13$ & $0 \cdot 90$ & 0.65 \\
\hline $\mathrm{H}$ & 1.08 & $1 \cdot 43$ & 0.73 & $0 \cdot 22$ & $0 \cdot 70$ & 0.33 & $0 \cdot 20$ & 0.59 & $0 \cdot 29$ & 0.75 & $0 \cdot 32$ & 0.87 \\
\hline
\end{tabular}

infected mouse is shown in Fig. 2. Since the colony signals from six output pools were not absolutely reproducible, the integrated density of each colony's dot blot signal from the autoradiographs derived from the input pool and the output pool from five mice was assessed by a computerized gel documentation system. Data were pooled and mean densities (Table 1) for bladder samples from five mice revealed that two 
(a)

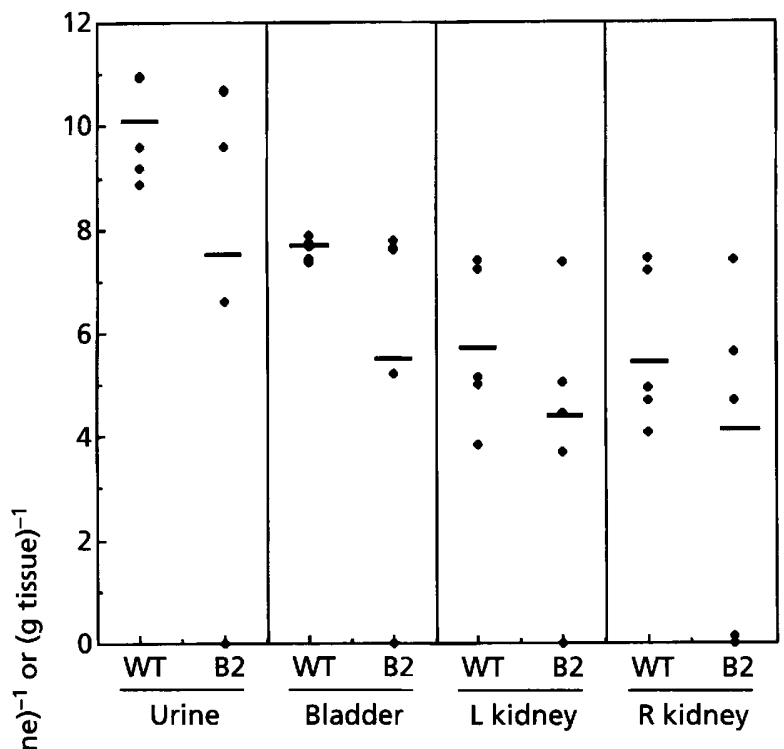

(b)

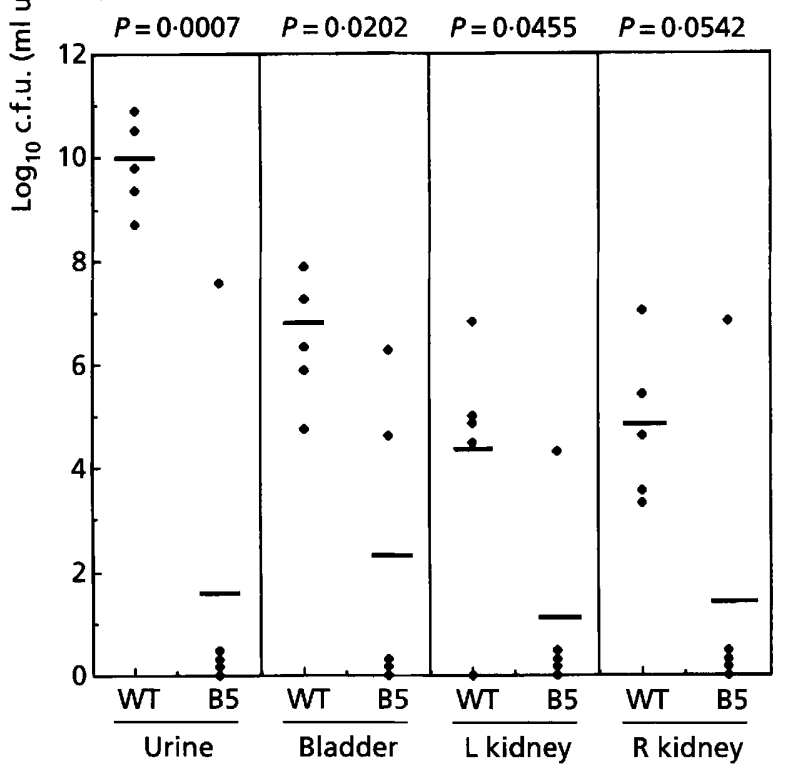

Fig. 3. Assessment of the virulence of (a) B2 and (b) B5 mutants in the CBA mouse model of ascending UTI. Mice were cochallenged with each mutant and the $P$. mirabilis parental strain. After 1 week of infection, the mice were killed and c.f.u. ( $\mathrm{ml}$ urine $)^{-1}$ or (g tissue) ${ }^{-1}$ of the mutant and wild-type strain were determined on kanamycin/tetracycline or tetracycline Luria agar plates, respectively. Horizontal lines represent the geometric mean of the colony counts. $P$ values were derived by using an unpaired $t$-test. For the B2 mutant, $P>0.05$; for the B5 mutant, $P$ values are shown above the figure. WT, Wild-type strain $P$. mirabilis HI4320; $L$, left; $R$, right.

mutants were reproducibly unrecoverable. These mutants, designated B2 and B5, were identified as those with attenuated virulence. Surprisingly, neither the auxotrophic mutants (E12, F12) nor the swarming mutants (G12, H12) included in this input pool were significantly attenuated.

\section{Confirmation of attenuation by experimental infection}

Of 96 transposon mutants tested, two mutants, B2 and $\mathrm{B} 5$, were consistently not recovered or recovered in negligible numbers. To confirm the attenuated virulence of these mutants, mice were transurethrally cochallenged with $5 \times 10^{6}$ c.f.u. each (total $10^{7}$ c.f.u. $\mathrm{ml}^{-1}$ ) of one mutant and wild-type strain. After 1 week, mice were killed and the mutant and wild-type strain were recovered and enumerated on Luria agar containing kanamycin and tetracycline (detects mutant only) or Luria agar containing only tetracycline (detects mutant plus wild-type), respectively. $\log _{10}$ c.f.u. (ml urine) $)^{-1}$ and $\left(\mathrm{g}\right.$ bladder $/ \mathrm{kidney}^{-1}$ were determined (wild-type vs mutant) for the B2 mutant $(n=5)$ (urine, 9.92 vs 7.51 ; bladder, 7.62 vs 5.60 ; and kidneys, 5.70 vs $3.83 ; P>0.05$ ) and for the B5 mutant $(n=5)$ (urine, 9.86 vs $1.52, P=$ 0.001 ; bladder, 6.43 vs $2.19, P=0.02$; and kidneys, 4.52 vs $1 \cdot 13, P=0.05$ ) (Fig. 3).

\section{Identification of interrupted genes}

To identify the nature of the attenuated transposon mutants, the interrupted genes were cloned from the B2 and B5 mutants and sequenced. Chromosomal DNA was isolated from each mutant and digested separately with EcoRV, SmaI, PvuII and DraI (all are predicted to cut within the transposon). Using the kanamycinresistance gene from transposon $\operatorname{Tn} 5$ as probe, Southern blot hybridization showed that the B2 mutant, digested with EcoRV, produced a $\sim 10 \mathrm{~kb}$ hybridizing fragment and the B5 mutant digested with DraI produced a $2 \cdot 6 \mathrm{~kb}$ hybridizing fragment (data not shown). Therefore, EcoRV-digested B2 chromosomal DNA and DraIdigested B5 chromosomal DNA were used for ligation into the EcoRV-digested pBluescript $\mathrm{KS}(-)$ vector. Transformants were selected on Luria agar plates containing kanamycin. The DNA fragments interrupted with the Mini-Tn5 transposon were confirmed as being cloned by digestion with several restriction enzymes. Both of the chromosomal DNA fragments flanking the transposon were subcloned into pBluescript $\mathrm{KS}(-)$ and sequenced using $\mathrm{T} 3$ and $\mathrm{T} 7$ promoter sequences from the pBluescript vector as primers. ORFs were identified using Genepro (version 5.00; Riverside Scientific) and each of the putative ORFs was used to search for similar sequences in the NR (non-redundant) GenBank using BLAST (Table 2).

\section{Sequence analysis and characterization of the B2 mutation}

From B2 mutant subclones we determined $2 \cdot 3 \mathrm{~kb}$ of sequence data which includes sequence $(530 \mathrm{bp})$ upstream of the B2 ORF, the entire B2 ORF (1002 bp) and part of the sequence from a second ORF (793 bp) downstream of the B2 gene (GenBank accession no. AF088981). The first ORF which was interrupted by the transposon (after nucleotide 561 of this ORF) predicts a polypeptide of $37 \cdot 3 \mathrm{kDa}$. The two ORFs are $14 \mathrm{bp}$ apart 
Table 2. Homologues of $P$. mirabilis genes identified as virulence factors by signaturetagged mutagenesis

\begin{tabular}{|c|c|c|c|c|}
\hline $\begin{array}{l}\text { Interrupted } \\
\text { gene }\end{array}$ & $\begin{array}{c}\text { Product of the } \\
\text { homologous gene }\end{array}$ & Strain & $\begin{array}{l}\text { Accession } \\
\text { no. }\end{array}$ & $P^{*}$ \\
\hline \multirow[t]{5}{*}{ B2 } & Putative protease & Escherichia coli & P45527 & $1 \cdot 9 \mathrm{e}-194$ \\
\hline & & Haemophilus influenzae & P44700 & $1.7 e-22$ \\
\hline & Collagenase & Escherichia coli & D90846 & $9 \cdot 8 \mathrm{e}-19$ \\
\hline & & Methanococcus jannaschii & B64311 & $3 \cdot 5 e-28$ \\
\hline & & Porphyromonas gingivalis & P33437 & $1 \cdot 7 \mathrm{e}-10$ \\
\hline \multirow[t]{4}{*}{ B5 } & ORF284 in the $r p o N$ & Escherichia coli & P33995 & $2 \cdot 8 \mathrm{e}-53$ \\
\hline & operon & Klebsiella pneumoniae & P17163 & $2 \cdot 8 \mathrm{e}-53$ \\
\hline & & Haemophilus influenzae & P45071 & $3 \cdot 3 e-36$ \\
\hline & & Bacillus subtilis & Z94043 & $8 \cdot 3 e-13$ \\
\hline
\end{tabular}

* $P$, Smallest sum probability. It contains the lowest $P$ value ascribed to any set of high-scoring segment pairs for each database sequence.

Table 3. Proteolytic activity of $P$. mirabilis and a signature-tagged mutant

Values are the mean and standard deviation of protease activity [proteolytic activity $A_{440}(\mathrm{ml}$ cell culture $)^{-1}$ ] detected by the azocasein protease assay (see Methods).

\begin{tabular}{|llll|}
\hline Strain & \multicolumn{3}{c|}{ Fraction } \\
\cline { 2 - 4 } & Supernatant & Periplasmic & Cytoplasmic \\
\hline Wild-type & $0.511 \pm 0.029$ & $0.032 \pm 0.016$ & $0.040 \pm 0.004$ \\
B2 mutant & $0.301 \pm 0.040^{*}$ & $0.011 \pm 0.001^{*}$ & $0.023 \pm 0.002^{*}$ \\
\hline
\end{tabular}

* Significantly lower than wild-type: supernatant, $P<0.0001$; periplasmic fraction, $P=0.0115$; cytoplasmic fraction, $P<0 \cdot 0001$.

and each of them has a ribosome-binding site upstream of their start codon. Although the promoter has not been identified, it is very likely that both ORFs would use the same promoter found upstream of the B2 ORF. One hundred and ninety-eight base pairs upstream of the B2 ORF a $330 \mathrm{bp}$ ORF is predicted to be transcribed in the opposite direction to that of B2. The second ORF was found to share amino acid similarity with products of genes of unknown function from $E$. coli.

By hydropathy analysis, the amino-terminal sequence (ELLCPAGNLPALKAAIENGADA) of the $\mathrm{B} 2$ protein is predicted to be relatively hydrophobic but does not fit to the classical signal peptide specifications. From the SWISS-PROT Sequence Bank (release 35.0, August, 1997), we found that the B2 gene and its homologues belong to a peptidase family called U32, the function of which is still not understood. In this family, only one gene, prtC, a protease gene from Porphyromonas gingivalis, has been well characterized. It was reported that $p r t C$ encoded a collagenase capable of cleaving type I collagen (Kato et al., 1992).

To investigate the function and localization of the B2 protein, proteolytic activity of the wild-type strain and B2 mutant strain was tested using an azocasein proteolytic assay (Table 3). The B2 mutant had significantly less $(P=0 \cdot 0001)$ proteolytic activity than the wild-type strain, consistent with the $\mathrm{B} 2$ gene encoding a protease. Most of the protease activity partitioned with the extracellular fraction, suggesting that the protease is secreted.

\section{Characterization of the B5 mutant}

The gene interrupted in the B5 mutant (GenBank accession no. AF088980) is an 855 bp ORF predicting a polypeptide of $32.6 \mathrm{kDa}$ which is highly similar to ORF284 in the rpoN operon of E. coli and Klebsiella pneumoniae (Jones et al., 1994). We also have complete sequence from the B5 downstream gene, which appears to be very similar to $n p r$ of the $r p o N$ operon (Fig. 4). The rpoN operon encodes RNA polymerase $\sigma^{54}$ factor, which is required for expression of a wide variety of nitrogenregulated genes including glutamine synthetase $(g \ln A)$. Therefore, to determine the effect of the B5 mutant on $\sigma^{54}$ activity, we assessed glutamine synthetase activity from wild-type and B5 mutant strains. Three ammonia concentrations were used: 1,3 and $20 \mathrm{mM} \mathrm{NH}_{4} \mathrm{Cl}$ in $\mathrm{M} 9$ minimal salts medium. In 3 and $20 \mathrm{mM} \mathrm{NH}_{4} \mathrm{Cl}$, we did not find any significant difference in the glutamine synthetase activity of the wild-type and B5 mutant. However, when only $1 \mathrm{mM} \mathrm{NH}_{4} \mathrm{Cl}$ was used as sole 


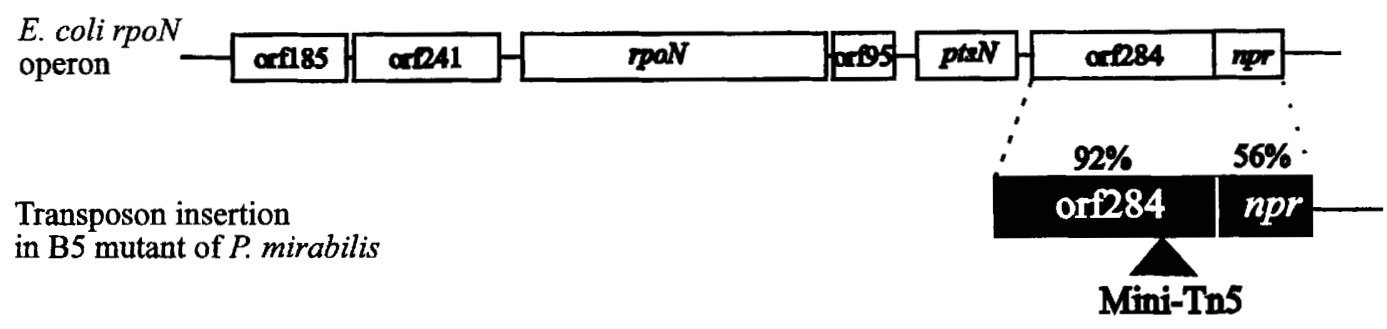

Fig. 4. Interrupted ORF in the B5 mutant and its homologue in the $E$. coli rpoN operon. Two ORFs were identified within 1297 nucleotides (black boxes). The first ORF predicts a polypeptide of $32.6 \mathrm{kDa}$ and shares amino acid sequence identity with ORF284 of the $E$. coli rpoN operon. The GenBank accession number for this sequence is AF088980. The transposon insertion site (black triangle) and the DNA region that has been sequenced is shown between the two dotted lines. Percentages represent the amino acid sequence identity between the products of homologous genes.

nitrogen source, glutamine synthetase activity was reduced in the mutant as compared to the wild-type strain (data not shown).

To assess the possibility that the attenuated virulence of B5 was due to a defect in the expression of other putative virulence genes, urease activity and expression of $M R / P$ fimbriae were evaluated. Using a urease assay (Jones \& Mobley, 1988), we detected the same level of urease activity from the wild-type and from the B5 mutant. Using a haemagglutination assay, both the wild-type and the B5 mutant were tested for the ability to haemagglutinate chicken erythrocytes in the presence of mannose. We found that the B5 mutant can haemagglutinate as well as the wild-type, indicating that, at least in vitro, the mutation in the B5 gene would not affect MR/P fimbriae expression (Bahrani \& Mobley, 1994; Zhao et al., 1997).

We also wanted to find whether the attenuation of virulence was due to poor growth of the B5 mutant in urine. Since the urea concentration in urine is about 400-500 mM (Griffith et al., 1976), urine can be classified as a very nitrogen rich medium. However, it is hard to assess growth in urine in vitro because $P$. mirabilis urease hydrolyses urea, elevates $\mathrm{pH}$ and causes ion precipitation. Therefore, we used M9 minimal medium containing different concentrations of nitrogen sources. Growth rates of the wild-type strain and the B5 mutant were determined in nitrogen-limited media $(10 \mathrm{mM}$ glutamine or arginine) and nitrogen-excessive media (400 $\mathrm{mM}$ and $800 \mathrm{mM} \mathrm{NH} \mathrm{NH}_{4} \mathrm{Cl}$ ). We found that the growth rate of the B5 mutant was not altered with respect to the wild-type strain in nitrogen-limited media (10 $\mathrm{mM}$ glutamine or arginine) but was slightly (not significantly different) reduced in nitrogen-excessive media $\left(400 \mathrm{mM} \mathrm{NH}_{4} \mathrm{Cl}\right)$. Neither wild-type nor B5 mutant could grow in medium containing $800 \mathrm{mM}$ $\mathrm{NH}_{4} \mathrm{Cl}$ (data not shown).

\section{DISCUSSION}

In contrast to in vivo expression technology (Mahan et al., 1993) which uses positive selection, signature-tagged mutagenesis is a genetic approach for identifying puta- tive virulence genes by negative selection in animal models of infection. In our studies, using signaturetagged mutagenesis, two previously unidentified genes involved in virulence have been isolated and characterized. Mutations in these genes result in attenuation of $P$. mirabilis HI 4320 in an experimental mouse model of UTI. Two days after transurethral challenge, a protease mutant was recovered in numbers 100 -fold less than the parental strain. A mutant in what appears to be a $\sigma^{54}$ operon was recovered in numbers over 1000 -fold less than the parental strain from urine, bladder and kidneys. Since the function of these two mutated genes had not previously been recognized, signature-tagged mutagenesis has proven to be a viable approach to identify genes associated with the ability to infect the urinary tract.

Unlike the animal model from the $S$. typhimurium studies (Hensel et al., 1995) which has very strong selective capabilities, our CBA mouse model of ascending UTI did not allow us to identify the attenuated mutants in every experiment. Some mutants in addition to the two reproducibly unrecoverable mutants were lost during individual experiments. This may have been due to the open route of the urinary tract where bacteria can easily be flushed out by urine flow. Therefore, as opposed to only two mice being necessary to identify $S$. typhimurium mutants, we had to challenge a higher number of mice $(n=7)$ and pool the results to identify a reproducible pattern. We also had to modulate the infection period from $7 \mathrm{~d}$ to $2 \mathrm{~d}$, since $7 \mathrm{~d}$ infection, which has been used in most of our previous animal infection studies, may have eliminated many mutants with perhaps only slight reductions in virulence. In addition, it appeared more difficult to obtain reproducible results from kidneys; we found that even the blotting of mutants from two kidneys from the same mouse gave quite different results. This is undoubtedly a result of the lower numbers of organisms (usually a total of $10^{4}$ c.f.u. $\mathrm{g}^{-1}$ or only a mean of $\sim 10^{2}$ c.f.u. for each mutant) that characteristically are recovered from an infected kidney.

The protease gene, identified through signature-tagged mutagenesis, appears to represent a virulence deter- 
minant, since mutation of the gene attenuates virulence in the mouse model of ascending UTI. This gene is homologous with genes encoding putative proteases or collagenases and appears to encode a secreted product. Thus far, an IgA-degrading protease (ZapA) is the only protease that has been identified in $P$. mirabilis (Wassif et al., 1995) and no virulence studies have yet been conducted using isogenic mutants. However, alignment of the respective predicted amino acid sequences demonstrates that there is no similarity between the B2 gene product and this IgA-degrading protease or to those of other mucosal pathogens including Neisseria gonorrhoeae (Plaut et al., 1975) and Haemophilus influenzae (Plaut, 1983). Instead, the B2 gene encodes a protein that is related to the U32 peptidase family. In this family, only PrtC from Porph. gingivalis has been characterized as a collagenase. In their review, Häse \& Finkelstein (1993) classified PrtC collagenase in the calcium-containing metalloprotease family. A spontaneous mutant of a Porph. gingivalis strain, which was attenuated for virulence in a rodent model system, was defective in several potential virulence characteristics including the collagenase activity (Shah et al., 1989). These data suggested that collagenase could be a virulence factor. However, isogenic mutants have not been tested.

UTIs by Proteus spp. can result in severe histological damage, resulting from development of acute pyelonephritis, calculi formation and renal impairment (Mobley, 1996). This damage could partly be explained by the action of proteases. Extracellular bacterial proteases from a number of pathogenic organisms have been demonstrated to play important roles in virulence. By degrading host tissue substrates like collagen, fibronectin and proteinaceous receptors, these enzymes can destroy host mucosal or skin barriers (Häse \& Finkelstein, 1993) and promote pathogen colonization (Kontani et al., 1997). By degrading immunoglobulin or serum complement components, they may also avoid the host immune response (Häse \& Finkelstein, 1993). By facilitating detachment of the pathogen from the initial niche, they can help infection to spread (Finkelstein et al., 1992). Finally, by acting as toxins, they can enhance vascular permeability (Chowdhury et al., 1991) or cause mucosal haemorrhage (Brunder et al., 1997).

It is interesting that a secreted protease was identified by this method. One might expect that members of the input pool could complement the defect in the B2 mutant, i.e. protease secreted by the other 95 members of the input pool should be capable of supplying the protease missing from the B2 mutant. There is actually some evidence for what has been called 'soft attenuation'. When the B2 mutant is placed into direct competition with the wild-type strain (Fig. 3a), a dramatic attenuation is not observed as for the B5 mutant. Indeed, although the sample size is small (five mice in each group) and the $P$ values approach levels of significance, the mutant when co-infected with the wildtype still displays some limited potential for colonization. It would be interesting to compare levels of colonization in groups of mice challenged separately with either the mutant or the wild-type strain alone.

Another putative virulence gene is the B5 gene, which is very similar to ORF284 of the rpoN operon. The $r p o N$ operon encodes $\sigma^{54}$ factor for RNA polymerase (Jones et al., 1994; Merrick \& Coppard, 1989; Powell et al., 1995). Many cellular functions depend on activation of transcription by a $\sigma^{54}$ promoter, most of which are related to cellular nitrogen assimilation and nitrogen fixation; others include decarboxylate transport, pilin and flagellin synthesis and urea utilization (Merrick, 1993; Merrick \& Edwards, 1995). Thus far, seven ORFs have been identified in the $r p o N$ operon of $E$. coli. Since the two genes we identified are almost identical to ORF284 $(92 \%$ amino acid sequence identity of predicted polypeptides) and $n p r(56 \%$ amino acid sequence identity) of the rpoN operon, we propose that $P$. mirabilis also has an rpoN operon. Two downstream ORFs, $p t s N$ and $n p r$, in the $r p o N$ operon are homologous with the IIA enzyme (specific for fructose and mannitol transport) and HPr in the phosphoenolpyruvate-dependent phosphotransferase systems (PTS) (Jones et al., 1994; Powell et al., 1995). The primary function for the PTS system is for sugar reception, transport and phosphorylation. The secondary function is to mediate metabolic and transcriptional regulation (Saier \& Reizer, 1994). Moreover, it was reported in K. pneumoniae that mutation in ORF95 and pts $N$ could elevate $\sigma^{54}$ activity (Merrick \& Coppard, 1989). Therefore, it has been suggested that the rpoN operon represents a link that may coordinate carbon and nitrogen metabolism in the bacterial cell (Jones et al., 1994; Merrick, 1993) and these downstream ORFs might provide a means for sensing nutritional status and regulating $\sigma^{54}$ activity by phosphorylation (Imaishi et al., 1993; Reizer et al., 1992). Since the B5 mutation does not significantly alter growth of $P$. mirabilis in vitro, it must exert its effect by altering expression of critical but as yet undetected genes that are expressed in vivo.

Based on this information, we have made an effort to investigate the contribution to virulence of the B5 gene. We have determined bacterial growth rate in nitrogenlimited and -sufficient media, tested the glutamine synthetase activity in nitrogen-limited and -sufficient media, and measured the expression of the other virulence factors including urease and $M R / P$. Unlike the $\sigma^{54}$-promoter-dependent urease gene in Klebsiella sp., urease activity in $P$. mirabilis is controlled by a ureadependent AraC-like positive transcriptional activator (UreR) (Nicholson et al., 1993) and thus this activity was not altered in the B5 mutant. MR/P fimbriae expression also did not change. Because urine is a nitrogen-sufficient and sugar-depleted medium, the mutation in ORF284 (B5) might affect bacterial growth in the urinary tract. However, we did not find any significant difference between the wild-type and B5 mutant of growth rate in nitrogen-limited, nitrogen-excessive and sugar-deficient M9 media. There was evidence that the synthesis of glutamine synthetase was reduced when $\mathrm{NH}_{4} \mathrm{Cl}$ as sole nitrogen source was limited to $1 \mathrm{mM}$. Therefore, mu- 
tation in B5 most likely affects expression of classic nitrogen-regulated genes and as yet undetected but critical nitrogen-regulated genes that play a key role in survival of the organism during UTI of the host.

\section{ACKNOWLEDGEMENTS}

This work was supported by Public Health Service DK49720 from the National Institute of Health. We thank Chris Tang and David Holden for providing the signature-tagged plasmid pool, technical protocol, frequent support and encouragement. We are also very grateful to Virginia Lockatell for animal inoculation and quantitative culture.

\section{REFERENCES}

Allison, C. \& Hughes, C. (1991). Closely linked genetic loci required for swarm cell differentiation and multicellular migration by Proteus mirabilis. Mol Microbiol 5, 1975-1982.

Allison, C., Emody, L., Coleman, N. \& Hughes, C. (1994). The role of swarm cell differentiation and multicellular migration in the uropathogenicity of Proteus mirabilis. JInfect Dis 169, 1155-1158.

Bahrani, F. K. \& Mobley, H. L. T. (1994). Proteus mirabilis MR/P fimbrial operon: genetic organization, nucleotide sequence, and conditions for expression. J Bacteriol 176, 3412-3419.

Bahrani, F. K., Massad, G., Lockatell, C. V., Johnson, D. E., Russell, R., Warren, J. W. \& Mobley, H. L. T. (1994). Construction of a MR/P fimbrial mutant of Proteus mirabilis: role in virulence in a mouse model of ascending urinary tract infection. Infect Immun 62, 3363-3371.

Belas, R. \& Flaherty, D. (1994). Sequence and genetic analysis of multiple flagellin-encoding genes from Proteus mirabilis. Gene $128,33-41$.

Belas, R., Erskine, D. \& Flaherty, D. (1991a). Transposon mutagenesis in Proteus mirabilis. J Bacteriol 173, 6289-6293.

Belas, R., Erskine, D. \& Flaherty, D. (1991b). Proteus mirabilis mutants defective in swarmer cell differentiation and multicellular behavior. J Bacteriol 173, 6279-6288.

Bender, R. A., Janssen, K. A., Resnick, A. D., Blumenberg, M., Foor, F. \& Magasanik, B. (1977). Biochemical parameters of glutamine synthetase from Klebsiella aerogenes. J Bacteriol 129, 1001-1009.

Brunder, W., Schmidt, H. \& Karch, H. (1997). EspP, a novel extracellular serine protease of enterohaemorrhagic $E$. coli O157: H7 cleaves human coagulation factor V. Mol Microbiol 24, $767-778$

Chiang, S. L. \& Mekalanos, J. J. (1998). Use of signature-tagged transposon mutagenesis to identify Vibrio cholerae genes critical for colonization. Mol Microbiol 27, 797-805.

Chowdhury, M. A., Miyoshi, S. \& Shinoda, S. (1991). Vascular permeability enhancement by Vibrio mimicus protease and the mechanisms of action. Microbiol Immunol 35, 1049-1058.

Finkelstein, R. A., Boesman-Finkelstein, M., Chang, Y. \& Hase, C. C. (1992). Vibrio cholerae hemagglutinin/protease, colonial variation, virulence, and detachment. Infect Immun 60, 472-478.

Griffith, D. P., Musher, D. M. \& Itin, C. (1976). Urease: the primary cause of infection-induced urinary stones. Investig Urol 13, 346-350.

Hagberg, L., Engberg, I., Freter, R., Lam, J., Olling, S. \& SvanborgEden, C. (1983). Ascending unobstructed urinary tract infection in mice caused by pyelonephritogenic Escherichia coli of human origin. Infect Immun 40, 273-283.
Hamilton-Miller, J. M. T. \& Gargan, R. A. (1977). Rapid screening for urease inhibitors. Investig Urol 16, 327-328.

Häse, C. C. \& Finkelstein, R. A. (1993). Bacterial extracellular zinccontaining metalloproteases. Microbiol Rev 57, 823-837.

Hensel, M., Shea, J. E., Gleeson, C., Jones, M. D., Dalton, E. \& Holden, D. W. (1995). Simultaneous identification of bacterial virulence genes by negative selection. Science 269, 400-403.

Hu, L.-T., Nicholson, E. B., Jones, B. D., Lynch, M. J. \& Mobley, H. L. T. (1990). Morganella morganii urease: purification, characterization, and isolation of gene sequences. J Bacteriol 172 , 3073-3080.

Imaishi, H., Gomada, M., Inouye, S. \& Nakazawa, A. (1993). Physical map location of the rpoN gene of Escherichia coli. J Bacteriol 175, 1550-1551.

Johnson, D. E., Lockatell, C. V., Hall-Craigs, M., Mobley, H. L. T. \& Warren, J.W. (1987). Uropathogenicity in rats and mice of Providencia stuartii from long-term catheterized patients. $J$ Urol 138, 632-635.

Johnson, D. E., Russell, R. G., Lockatell, C. V., Zulty, J. C. \& Warren, J. W. (1993a). Urethral obstruction of 6 hours or less causes bacteriuria, bacteremia, and pyelonephritis in mice challenged with 'nonuropathogenic' Escherichia coli. Infect Immun 61, 3422--3428.

Johnson, D. E., Russell, R. G., Lockatell, C. V., Zulty, J. C., Warren, J. W. \& Mobley, H. L. T. (1993b). Contribution of Proteus mirabilis urease to persistence, urolithiasis, and acute pyelonephritis in a mouse model of ascending urinary tract infection. Infect Immun 61, 2748-2754.

Jones, B. D. \& Mobley, H. L. T. (1987). Genetic and biochemical diversity of ureases of Proteus, Providencia, and Morganella species isolated from urinary tract infection. Infect Immun $\mathbf{5 5}$, 2198-2202.

Jones, B. D. \& Mobley, H. L. T. (1988). Proteus mirabilis urease genetic organization, regulation, and expression of structural genes. J Bacteriol 170, 3342-3349.

Jones, B. D., Lockatell, C. V., Johnson, D. E., Warren, J. W. \& Mobley, H. L. T. (1990). Construction of a urease-negative mutant of Proteus mirabilis: analysis of virulence in a mouse model of ascending urinary tract infection. Infect Immun 58, 1120-1123.

Jones, D. H. A., Franklin, F. C. H. \& Thomas, C. M. (1994). Molecular analysis of the operon which encodes the RNA polymerase sigma factor $\sigma^{54}$ of Escherichia coli. Microbiology 140, 1035-1043.

Kato, T., Takahashi, N. \& Kuramitsu, H. K. (1992). Sequence analysis and characterization of the Porphyromonas gingivalis prtC gene, which expresses a novel collagenase activity. $J$ Bacteriol 174, 3889-3895.

Kontani, M., Kimura, S., Nakagawa, I. \& Hamada, S. (1997). Adherence of Porphyromonas gingivalis to matrix proteins via a fimbrial cryptic receptor exposed by its own arginine-specific protease. Mol Microbiol 24, 1179-1187.

Loomes, L. M., Senior, B. W. \& Kerr, M. A. (1990). A proteolytic enzyme secreted by Proteus mirabilis degrades immunoglobulins of the immunoglobulin A1(IgA1), IgA2, and IgG isotypes. Infect Immun 58, 1979-1985.

Lorenzo, V., Herrero, M., Jakubzik, U. \& Timmis, K. N. (1990). Mini-Tn5 transposon derivatives for insertion mutagenesis, promoter probing, and chromosomal insertion of cloned DNA in Gram-negative eubacteria. J Bacteriol 172, 6568-6572.

Mahan, M. J., Slauch, J. M. \& Mekalanos, J. J. (1993). Selection of bacterial virulence genes that are specifically induced in host tissues. Science 259, 686-688. 
Massad, G., Lockatell, C. V., Johnson, D. E. \& Mobley, D. E. (1994). Proteus mirabilis fimbriae: construction of an isogenic $p m f A$ mutant and analyses of virulence in a CBA mouse model of ascending urinary tract infection. Infect Immun 62, 536-542.

Massad, G., Zhao, H. \& Mobley, H. L. T. (1995). Proteus mirabilis amino acid deaminase: cloning, nucleotide sequence, and characterization of aad. J Bacteriol 177, 5878-5883.

Mei, J. M., Nourbakhsh, F., Ford, C. W. \& Holden, D. W. (1997). Identification of Staphylococcus aureus virulence genes in a murine model of bacteraemia using signature-tagged mutagenesis. Mol Microbiol 26, 399-407.

Merrick, M. J. (1993). In a class of its own - the RNA polymerase sigma factor $\sigma^{54}\left(\sigma^{\mathrm{N}}\right)$. Mol Microbiol 10, 903-909.

Merrick, M. J. \& Coppard, J. R. (1989). Mutations in genes downstream of the $r p o N$ gene (encoding $\sigma^{54}$ ) of Klebsiella pneumoniae affect expression from $\sigma^{54}$-dependent promoters. Mol Microbiol 3, 1765-1775.

Merrick, M. J. \& Edwards, R. A. (1995). Nitrogen control in bacteria. Microbiol Rev 59, 604-622.

Mobley, H. L. T. (1996). Virulence of Proteus mirabilis. In Urinary Tract Infection: Molecular Pathogenesis and Clinical Management, pp. 245-271. Edited by H. L. T. Mobley \& J. W. Warren. Washington, DC: American Society for Microbiology.

Mobley, H. L. T. \& Belas, R. (1995). Swarming and pathogenicity of Proteus mirabilis in the urinary tract. Trends Microbiol 3, 280-284.

Mobley, H. L. T. \& Warren, J. W. (1987). Urease-positive bacteriuria and obstruction of long-term urinary catheters. $J$ Clin Microbiol 25, 2216-2217.

Mobley, H. L. T., Chippendale, G. R., Swihart, K. G. \& Welch, R. (1991). Cytotoxicity of the HpmA hemolysin and urease of Proteus mirabilis and Proteus vulgaris against cultured human renal proximal tubular epithelial cells. Infect Immun 59, 2036-2042.

Mobley, H. L. T., Belas, R., Lockatell, C. V., Chippendale, G., Trifillis, A., Johnson, D. E. \& Warren, J. W. (1996). Construction of a flagellum-negative mutant of Proteus mirabilis: effect and internalization by human renal epithelial cells and virulence in a mouse model of ascending urinary tract infection. Infect Immun 64, 5332-5340.

Nicholson, E. B., Concaugh, E. A., Foxall, P. A., Island, M. D. \& Mobley, H. L. T. (1993). Proteus mirabilis urease: transcriptional regulation by ureR. J Bacteriol 175, 465-473.

Plaut, A. G. (1983). The $\operatorname{IgA} 1$ proteases of pathogenic bacteria. Annu Rev Microbiol 37, 603-622.

Plaut, A. G., Gilbert, J. V., Artenstein, M. S. \& Capra, J. D. (1975). Neisseria gonorrhoeae and Neisseria meningitidis: extracellular enzyme cleaves human immunoglobulin A. Science 190, 1103-1105.

Powell, B. S., Court, D. L., Inada, T., Nakamura, Y., Michotey, V., Cui, X., Reizer, A., Saier, M. H., Jr \& Reizer, J. (1995). Novel proteins of the phosphotransferase system encoded within the rpoN operon of Escherichia coli. J Biol Chem 270, 4822-4839.

Reizer, J., Reizer, A., Saier, M. H., Jr \& Jacobson, G. R. (1992). A proposed link between nitrogen and carbon metabolism involving protein phosphorylation in bacteria. Protein Sci 1, 722-726.

Rubin, R., Tolkoff-Rubin, N. \& Cotran, R. (1986). Urinary tract infection, pyelonephritis and reflux nephropathy. In The Kidney, 3rd edn, pp. 1085-1141. Edited by G. Brenner \& F. Rector, Jr. Philadelphia: W. B. Saunders.

Saier, M. H., Jr \& Reizer, J. (1994). The bacterial phosphotransferase system: new frontiers 30 years later. Mol Microbiol 13, 755-764.

Schwan, W. R., Silvija, N. C., Ng, E. Y. W. \& 7 other authors (1998). Identification and characterization of the PutP proline permease that contributes to in vivo survival of Staphylococcus aureus in animal models. Infect Immun 66, 567-572.

Senior, B. W., Albrechtsen, M. \& Kerr, M. A. (1987). Proteus mirabilis strains of diverse type have IgA protease activity. $J$ Med Microbiol 24, 175-180.

Senior, B. W., Loomes, L. M. \& Kerr, M. A. (1991). The production and activity in vivo of Proteus mirabilis IgA protease in infections of the urinary tract. J Med Microbiol 35, 203-207.

Setia, U., Serventi, I. \& Lorenz, P. (1984). Bacteremia in a longterm care facility: spectrum and mortality. Arch Intern Med 144 , 1633-1635.

Shah, H. N., Seddon, S. U. \& Gharbia, S. E. (1989). Studies on the virulence properties and metabolism of pleiotropic mutants of Porphyromonas gingivalis W50. Oral Microbiol Immunol 4, 19-23.

Shea, J. E., Hensel, M., Gleeson, C. \& Holden, D. W. (1996). Identification of a virulence locus encoding a second type III secretion system in Salmonella typhimurium. Proc Natl Acad Sci USA 93, 2593-2597.

Swihart, K. G. \& Welch, R. A. (1990). Cytotoxic activity of the Proteus hemolysin HpmA. Infect Immun 58, 1861-1867.

Warren, J. W., Tenney, J. H., Hoopes, J. M., Muncie, H. L. \& Anthony, W. C. (1982). A prospective microbiologic study of bacteriuria in patients with chronic indwelling urethral catheters. $J$ Infect Dis 146, 719-723.

Wassif, C., Cheek, D. \& Belas, R. (1995). Molecular analysis of a metalloprotease from P. mirabilis. J Bacteriol 177, 5790-5798.

Wright, D. K. \& Manos, M. M. (1990). Sample preparation from paraffin-embedded tissues. In PCR Protocols : a Guide to Methods and Applications, pp. 1153-1156. Edited by M. A. Innis, D. H. Gelfand, J. J. Sninsky \& T. J. White. New York : Academic Press.

Zhao, H., Li, X., Johnson, D. E., Blomfield, I. \& Mobley, H. L. T. (1997). In vivo phase variation of $M R / P$ fimbrial gene expression in Proteus mirabilis infecting the urinary tract. Mol Microbiol 23, 1009-1019.

Received 4 August 1998; revised 3 September 1998; accepted 17 September 1998. 